\title{
光方式電流センサ用希土類鉄ガーネット結晶
}

$\begin{array}{lllllll}\text { 足 員 和 田 } & \text { 道 夫 } & \text { (関西電力) } & \text { 非会員 } & \text { 石 塚 } & \text { 訓 } & \text { (松下電器) } \\ \text { 正員 } & \text { 不動 } & \text { 弘幸 } & \text { (関西電力) } & \text { 非会員 } & \text { 石河 大 典 } & \text { (松下電器) } \\ \text { 非会員 } & \text { 江川 } & \text { 進 } & \text { (関西電力) } & \text { 非会員 } & \text { 伊藤 伸 器 } & \text { (松下電器) }\end{array}$

\section{Rare-Earth Iron Garnets for Fiber Optic Current Sensors}

Michio Wada, Member, Hiroyuki Fudo, Member, Susumu Egawa, Non-member(Kansai Electric Power Co., Inc.), Satoshi Ishizuka, Non-member, Daisuke Ishiko, Non-member, Nobuki Itoh, Non-member (Matsushita Electric Industrial Co., Ltd.)

Fiber optic current sensors with temperature-independent sensitivity have been developed. For Faraday rotators of the sensors, highly $\mathrm{Bi}$-substituted rare-earth iron garnets, $\mathrm{Bi}_{x} \mathrm{Gd}_{Y} \mathrm{Y}_{3-(X+Y)}$ $\mathrm{Fe}_{5} \mathrm{O}_{12}$, are prepared by a liquid phase epitaxy (LPE) method. It is found that the temperature dependence of the sensitivity constants is improved by Gd substitution. The crystal with the components of $X=1.3$ and $Y=0.43$ is found to show the least temperature variation of the sensitivity constants within $\pm 0.5 \%$ between 253 and $353 \mathrm{~K}$. The sensor modules using the crystals have good characteristics in practical use. The sensor units for monitoring the condition of power distribution lines have high environmental durability, high insulation, and no electromagnetic induction.

\section{キーワード：光方式電流センサ, $\mathrm{Bi}$ 置換希士類鉄ガーネット結晶, ファラデー効果, 感度温度特性}

\section{1. 序論}

近年, 電力会社で注, 高度情報化社会に対応するた め, 開開器の遠隔制御を中心とした配電線自動運用シ ステムを主軸にして, 配電線総合自動化システムの研 究が行われている。開閉器の高度な遠隔制御を実施す るには，事故区間極小化や復旧の迅速化のための運転 状態のモ二タが不可欠となる。

このような背景から，ファラデー効果を利用した光 方式電流センサが, 高絶緑性, 而電磁誘道雑音性, 電 気的非接触測定が可能といつた利点から, 配電系統の 事故検出用センサとして開発されてきた( ${ }^{(1)}$ これれらの 光方式電流七ンサは, 屋外の配電線に設置して使用さ れることから, 室温付近の温度変化比して, 常に一 定の出力を与えることや耐環境性, 高信頼性が望まれ る。

電学論C, 112 巻 12 号, 平成 4 年
そこで著者らは, 光方式電流センサ用ファラデー素 子として, 材料組成を検討することにより, 高感度で 温度特性の優れた Bi 置換希土類鉄ガーネット結晶を 開発した。ここでは，材料の評価結果とセンサ特性扔 よび開発したセンサユニットについて報告する。

\section{2. 試料の準備と測定}

液相エピタキシャル成長 (LPE) 法を用いて [1 111$]$ 面方位 $(\mathrm{GdCa})_{3}(\mathrm{MgZrGa})_{5} \mathrm{O}_{12}$ 基板上纤, $\mathrm{Bi}$ 置換希 土類鉄ガーネット結晶を成長した。基板の格子定数

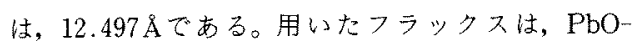
$\mathrm{Bi}_{2} \mathrm{O}_{3}-\mathrm{B}_{2} \mathrm{O}_{3}$ 系である。得られた結晶の組成は, $\mathrm{X}$ 線 マイクロアナライザで分析した。また, 結晶の膜厚 は, 分光器を用いて近赤外領域における干涉縞加求 めた。

結晶の感度定数の測定は, $223 \mathrm{~K}$ から $373 \mathrm{~K}$ の温度 
範囲に颃いて，ACあるいはDC磁界に対して平行 に, 発光中心波長 $0.85 \mu \mathrm{m}$ の LED 光を透過して行っ た。結晶の感度定数は, 印加磁界に対する正味のファ ラデー回転角の大きさから求められる。ここで, 正味 のファラデー回転奐とは, 光ビームの単位面積当たり のファラデー回転角の大きさである。実際には，結晶 の感度定数は印加磁界に対寸る光信号処理回路からの 出力 (変調度) から決定した。材料の磁気館和状態に おけるファラデー回転角は，日本分光製磁気光学測定 装置を用いて測定した。

\section{3. 光方式電流センサの原理と構成}

ファラデー効果は，媒質に磁界を印加したとき，光 の偏波面が光の伝搬上共に回転する現象である。反磁 性体や常磁性体に対するファラデー回転角 $(\Theta)$ は, 次 式で与えられる。

$\Theta=V H L$

ここで, $V:$ ベルデ定数であり媒筫固有の定

数, $H:$ 光の伝搬方向の磁界強度, $L:>ア$

ラデー素子の光路舆

図 1 に光方式電流センサの原理図を示す。偏光子と 検光子をファラデー素子の前後に相対角 45 度で配置 している。図のように構成したとき，センサからの出 射光量江次式で表される(2)。

$$
\begin{aligned}
P_{\text {out }} & =\alpha P_{\text {in }}(1+\sin 2 \Theta) \\
& =\alpha P_{\text {in }}(1+2 V H L)
\end{aligned}
$$

ここで， $\alpha$ は比例定数であり，ファラデー回転角 $\Theta$ が十分に小さい場合の $\sin \Theta \fallingdotseq \Theta の$ 近似を用いてい る。

従って, 印加磁界 $H$ が $H=H_{0} \sin \omega t$ で表されると き，上式に代入すると出射光量は次式のように表さ れ, 磁界強度に比例した光量变化が得られる。

$$
P_{\text {out }}=\alpha P_{\text {in }}\left\{1+2 V H_{0} L \sin \omega t\right\}
$$

センサを出射した光は，光ファイバで光信号処理回 路へ導かれ，(3) 式第 1 項の DC 成分と第 2 項の AC 成分を行けて割算され，変調度 $m(\%)$ として回路か

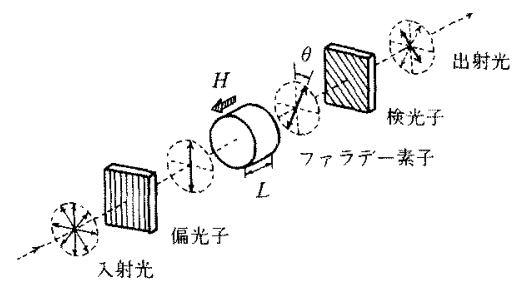

図 1 光方式電流センサの原理図

Fig. 1. Principle of fiber optic current sensor.
らの出力安得る。

しかしながら，本研究でファラデー素子に用いた希 土類鉄ガーネット結晶はフェリ磁性体であり，磁区構 造として迷路状やストライブ状パターンを形成する。 単磁区構造でないフェり磁性体には上記の原理は策純

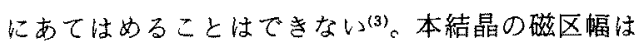
$10 \mu \mathrm{m}$ 程度であり, 磁区構造に起因する回折効果も考 慮する必要がある。従って, 入射光のビーム径は磁区 幅よりも十分に大きく，入射して結晶を透過した光 は，す心゙て出射側の光ファイバに集光するようにセン サモジュール光学系を構成することが必要となる。

\section{4. 実験結果と考察}

希土類鉄ガーネット結晶は，フェリ磁性体であるか ら，印加磁界が弱いときには多磁区構造をとる。正味 のファラデ一回転角は, 磁性体が磁気飽和状態（単磁 区）になったときに飽和する。この単磁区状態でのフ アラデー回転角をファラデー回転能 $\left(\Theta_{F}\right)$ と呼ぶ。光 方式電流センサには，正味のファラデー回転角が印加 磁界に対して比例変化する領域を用いる。結晶の感度 定数 $C$ は温度 $T$ の関数として次式で定军できる(4)。

$$
\begin{aligned}
& C(T)=\Theta_{F}(T) / M_{S}(T) \\
& こ こ て ゙, M_{S}: \text { 飽和磁化 }
\end{aligned}
$$

上式から，結昆の感度定数を大きくするためには， $\Theta_{F}$ が大きく $M_{S}$ が小さい結晶が必要であることがわ かる。更に, 室温付近で $\Theta_{F}(T)$ の温度変化と $M_{S}(T)$ の温度変化の割合が等しければ, $C(T)$ が全く温度依 存性を示さないことが期待できる。

そこで， $\Theta_{F}(T)$ をきくするために， $\mathrm{Y}_{3} \mathrm{Fe}_{5} \mathrm{O}_{12}$ 結 晶の $\mathrm{Y}$ 元素に Bi 元素を㯰換し，温度特性を改善する ために，更に Gd 元索を置換した。Gd元素を選択し たのは，Bi 置換量が大きいときには Gd 置換によっ て $\Theta_{F}(T)$ は変化しないが， $M_{S}(T)$ は室温付近で大き く変化するからである。

一般に，ガーネット構造に対しては三つの副格子 〔4 面体格子 $(d), 8$ 面体格子 $(a), 12$ 面体格子 $(c)$ ) 考えなければならない。Crossleyによれば，ファラ デ一回転能の温度変化は, 次式で表されるとしだ(5)。

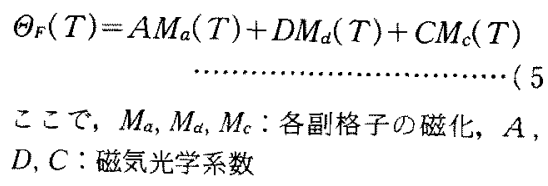

(5)式をもとに計算すると，Bi元素を多量に置換し たガーネット結晶の場合，C值は $A, D$ の值に比べて かなり小さい值となる 


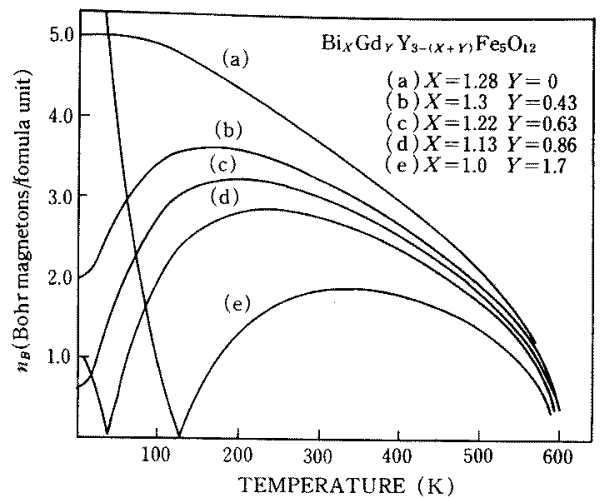

図 $2(\mathrm{BiGdY}) \mathrm{IG}$ 結晶の飽和磁化の計算結果 Fig. 2. Calculated results of $M_{S}(T)$ by the molecular field theory.

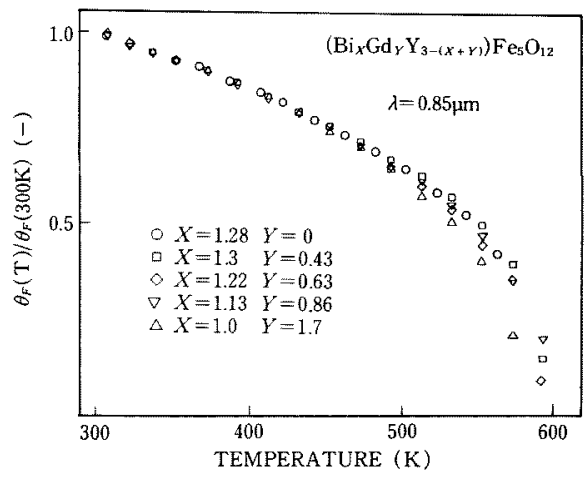

図 $3(\mathrm{BiGdY}) \mathrm{IG}$ 結晶の $\Theta_{F}(T)$ ○測定結果

Fig. 3. Temperature dependence of normalized Faraday rotation of $(\mathrm{BiGdY}) \mathrm{IG}$ at $0.85 \mu \mathrm{m}$.

対する $\mathrm{Gd}$ 置換の寄与は， $\mathrm{Bi}$ を多量に置換した場合 は無視できると考えられる。

フェリ磁性ガーネット結晶の飽和磁化の温度依存性 については，分子場理論によってよく説明されてい $ろ^{(7)(8)}$ 。単位体積当たりの磁気モーメントは, 次式で 与えられる。

$$
M_{s}(T)=\left|M_{d}(T)-M_{a}(T)+M_{c}(T)\right| \cdots(6)
$$

これら二つの理論から，(4)式老用いて $C(T)$ の温 度特性を計算することができる。

図 2 に分子場理論に上る $\left(\mathrm{Bi}_{X} \mathrm{Gd}_{Y} \mathrm{Y}_{3-(X+y)}\right) \mathrm{Fe}_{5} \mathrm{O}_{12}$ 結晶(以下（BiGdY)IGと略記)の飽和磁化の温度低 存性の計算結果を示す。この場合, Hansenらによっ て, Bi 置換による補頱温度とキュリー温度の変化を 考慮して導加れた $\mathrm{Gd}_{3} \mathrm{Fe}_{5} \mathrm{O}_{12}$ の分子場係数を用いて いる(9)(10)。図 2 からわかるように Gd 濃度が高くなる

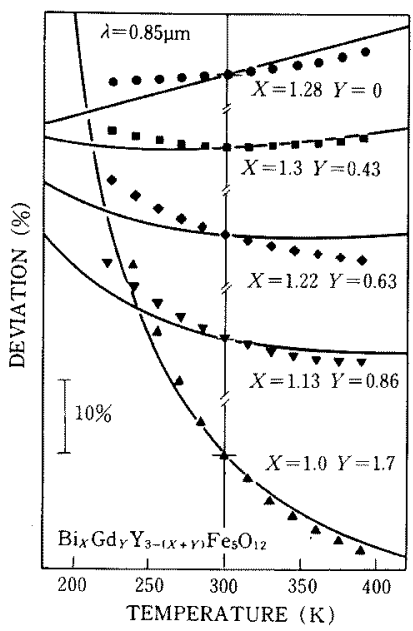

图 4 (BiGdY)IG 結晶の感度定数の温度依存性 Fig. 4. Temperature dependence of sensitivity constants of (BiGdY)IG.

につれて, 室温付近の $M_{s}(T)$ の温度変化が減少する ことがわかる。

奏際に5種類の組成の(BiGdY)IGを作製 , $\Theta_{F}(T)$ の温度依存性を測定した結果を図 3 に示す。 測定結果は，300 K で規格化されている。波長 0.85 $\mu \mathrm{m} て ゙ 300 \mathrm{~K}$ 加ら $600 \mathrm{~K}$ の温度箸用で測定した。 Bi 濃度はほぼ一定であり，Gd濃度は $0 \sim 1.7$ に変化し ている。Gd置換によって， $\Theta_{F}(T)$ は室温付近では特 に温度変化を示さないことがわかる。これらの結果か ら，5種類の組成に対して $A, D, C$ の係数を決定し， $\Theta_{F}(T) の$ 計算に用いた。

更に, 図 4 に $300 \mathrm{~K}$ で規格化された結晶の感度定 数の温度依存性の測定結果を示す。測定の温度範囲 は, 223〜373 Kである。プロットした点が奏測值で あり, 実線が $M_{S}$ と $\Theta_{F}$ の理諭值を用いて(4)式から 求めた計算值である。実験結果と計算結果はよい一致 を本している。結果として, $\left(\mathrm{Bi}_{1,3} \mathrm{Gd}_{0.43} \mathrm{Y}_{1.27}\right) \mathrm{Fe}_{5} \mathrm{O}_{12}$ の組成をもつ結晶の感度定数が, $253 \mathrm{~K}$ から $353 \mathrm{~K} の$ 温度範囲で最小の $00.5 \%$ 以内の温度特性をもつこと が明らかとなった。この組成をもつ結晶の感度定数の 值は, 室温で $5.0^{\circ} /(0 \mathrm{e} \cdot \mathrm{cm})$ であり, 膜厚は $90 \mu \mathrm{m} て$ ある。また, 透過スペクトルから求めた波長 $0.85 \mu \mathrm{m}$ の光に対する結晶の吸収係数は, $250 \mathrm{~cm}^{-1}$ であた。

\section{5. 光方式電流センサモジュールと特性}

ファラデー素子に上記の( $\mathrm{BiGdY}) \mathrm{IG}$ 結晶を採用 し, 光方式電流センサを開発した。電流センサモジュ 


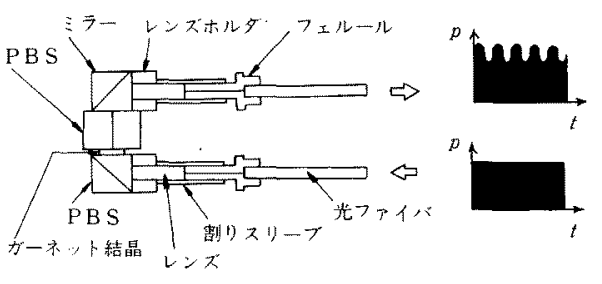

図 5 モジュール内部構成

Fig. 5. Construction of current sensor modules.

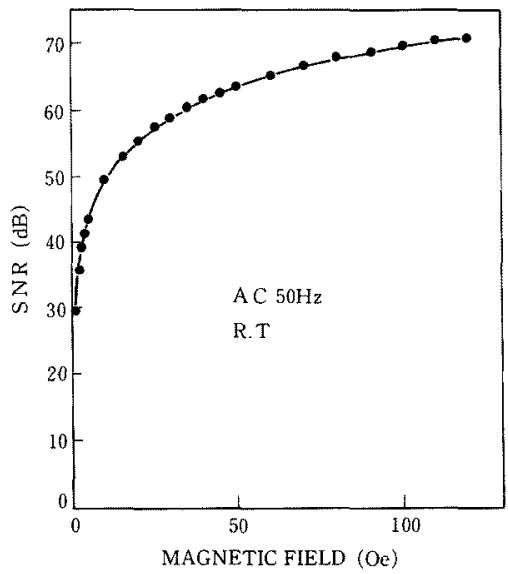

図 6 室温における磁界強度と $S N$ 比の関係

Fig. 6. Relationships between magnetic field and measured $S N$ ratio of the sensor output.

ールの構成を図 5 に示す。センサモジュールは, 結晶 と偏光子，検光子からなり，二つの偏光ビームスプリ ッ夕(PBS)の透過偏光方向は互いに 45 度傾けた光强 度変調タイプの構成とした。光ファイバはコア径 80 $\mu \mathrm{m}$ のマルチモードファイバを使羘し，芯線をセラミ ック製フェルールに捙入して，レンズ端面に接着して いる。コリメートレンズには，1/4ピッチの自己集束 性ロッドレンズを使用した。従って，結晶を透過する 光ビーム径は約 $1 \mathrm{~mm}$ である。ガーネット結晶は 3 $\mathrm{mm}$ 角に切断した後，鏡面研磨した。ミラーは立方体 型の全反射ミラーを用いている。PBSとミラーは一 辺 $5 \mathrm{~mm}$ の立方体である。それぞれの部品の接着には エポキシ系接着剂を使用し， $21 \times 29 \times 10 \mathrm{~mm}$ の スに固定した。

ファラデー素子には, 温度特性の最も良い $\left(\mathrm{Bi}_{1,3} \mathrm{Gd}_{0.43} \mathrm{Y}_{1.27}\right) \mathrm{Fe}_{5} \mathrm{O}_{12}$ 結晶を用いた。センサ特性と して, SN 比, 直線性䛊差, センサ出力の温度特性を

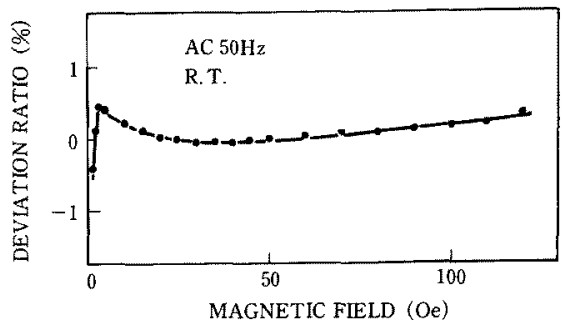

図 7 交流磁界に対するセンサ出力の 直線性望差

Fig. 7. Linearity deviation of sensor output vs. magnetic field.

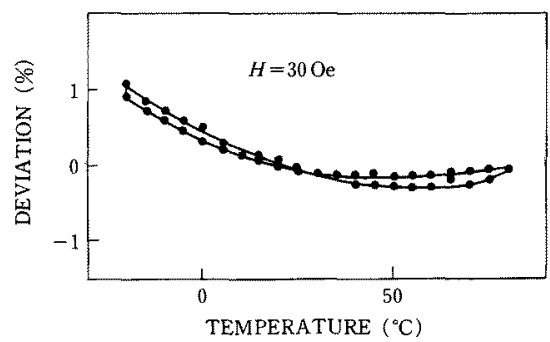

図 8 交流磁界に対するセンサ出力の温度変化 Fig. 8. Temperature variation of sensor output.

測定した。図 6 に室温における $50 \mathrm{~Hz}$ の AC 磁界強 度と $S N$ 比の関係を示す。最小検出感度 $(S / N=1)$ は, $0.04 \mathrm{Oe}$ である。図 7 に AC 磁界強度に対する直線性 誤差の測定結果を示す。120 Oeまでの磁界強度に対 して， $\pm 0.5 \%$ 以内の非線形㑟差を示している。 $30 \mathrm{Oe}$ の $\mathrm{AC}$ 磁界に対するセンサ出力の温度変化を図 8 に示 す。実用温度域であるー20〜 $+80^{\circ} \mathrm{C}$ 温度範囲におい て，士0.6\%以内の計測精度が得られている。センサ の温度変化は, 主に(BiGdY)IG 結晶の特性に起因し ていると考えられる。

\section{6. センサユニット構成}

電流センサは電線路に流れる電流によって生じる磁 界検知する。センサュニットには，電線路周辺の磁 界を効率良く電流センサ部に集中するために磁界周回 積分用コアを使用している。センサュニットの構造を 図 9 に示す。ュニット内には電気光学結晶のポッタル 效果を応用した光方式電圧センサも内蔵している。 侻って, 光ファイバは4芯ノンメタリックケーブルを 使用した。ケース材料はポリエチレン樹脂であり，内 部に設置した各部品を樹脂充媜により固定している。 


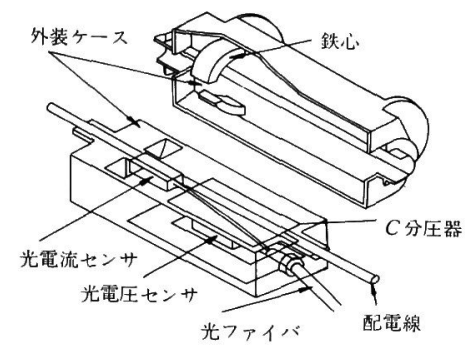

図 9 センサユニットの構造

Fig. 9. Construction of current sensor units.

ケースサイズは, $230 \times 110 \times 120 \times \mathrm{mm}$ であり, 重量 は約 $1.7 \mathrm{~kg}$ である。

\section{7. 結論}

光方式電流センサ用 $\mathrm{Bi}$ 置換希土類鉄ガーネット結 晶(BiGdY) IG L LPE 法を用いて作製した。結晶の 感度定数の測定から, $\left(\mathrm{Bi}_{1.3} \mathrm{Gd}_{0.43} \mathrm{Y}_{1.27}\right) \mathrm{Fe}_{5} \mathrm{O}_{12}$ 結晶が 253 353 K の温度範囲において $00.5 \%$ 以内の最小の 温度依存性をもつことが明らかとなった。 $\Theta_{F}$ の理論 と分子場理論から求めた計算結果は, 実験とよい一致 を示した。この結晶を用いた光方式電流センサモジュ ールは感度が高く, 温度に依存しない特性を有する。 また，開発したセンサユニットは，配電線上に設置す るには小型かつ軽量であり，降雨や積雪に対しても而 候性がよく安定な出力を与え, 配電線モニタリングセ ンサとして実用上問題のない特性を実現した ${ }^{(11)}$ 。

(平成 4 年 5 月 25 日受付)

\section{文献}

(1) K. Kurosawa : Proc. of 7 th Optical Fiber Sensors Conf. TUO 3-1, p. 67 (1990)

(2) K. Kyuma, S. Tai, M. Nunoshita, T. Takioka \& Y. Ida IEEE J. Q. E., QE-18, 1619 (1982)

（3）八尾・沼田・井ロ：電気学会マグネティクス研資, MAG-9275 (平 4 ).

(4) O. Kamada, H. Minemoto \& S. Ishizuka: J. Appl. Phys., 61, 3268 (1987)

(5) W. A. Crossley, R. W. Cooper, J. L. Page \& R. P. van Stapele: Phys. Rev., 181, 896 (1969)

(6) O.Kamada, H. Minemoto \& S. Ishizuka: Advances in Magneto-Optics, Proc. Int. Symp. Magneto-Optics, J. Magn. Soc. Jpn., 11, Supplement, No. S 1, 401 (1987)

(7) G.F. Dionne: J. Appl. Phys., 41, 4874 (1970)

(8) C.D. Brandle \& S. L. Blank: IEEE Trans. Magnetics, MAG-12, 14 (1976)

(9) P. Hansen, K. Witter \& W. Tolksdolf: Phys. Rev., 27, 4375 (1983)

(10) P. Hansen, K. Witter \& W. Tolksdolf : ibid., 27, 6608 (1983)

（11）石河, 他: National Tech. Rep., 38, No. 2127 (平 4)

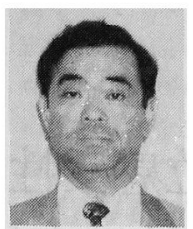

賞受賞。

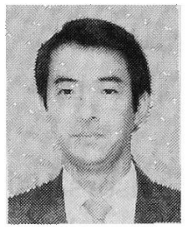

受賞。

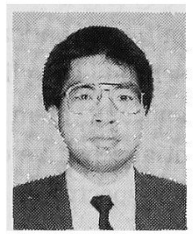

江川

進 (非会員)

昭和 35 年 6 月 10 日生。 56 年 3 月和 歌山工業高等専門学校電気工学科卒業。 56 年 4 月関西電力 (株) 入社。現在, 同 社配電部配電計画課。

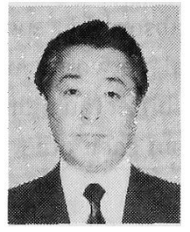

\section{石塚訓 (非会員)}

昭和 23 年 8 月 11 日生。 46 年 3 月秋 田大学電気工学科卒業。同年松下電器産 業(株)入社。現在, 同社ネットワーク開 発推進センター主任技師。平成 3 年度大 山松次郎賞受賞。

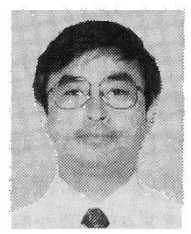

\section{石 河大 典 (非会員)}

昭和 24 年 11 月 7 日生。 43 年松下電 器産業 (株) 入社。6 61 年より光方式電流・ 電圧センサの研究開発に従事。現在, 同 社ネットワーク開発推進センター主任技

師。

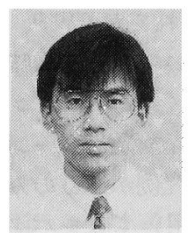

\section{伊藤 伸器 (非会員)}

昭和 39 年 1 月 11 日生。平成元年大阪 大学大学院基礎工学部修士課程修了。同 年松下電器産業 (株) 入社。光方式電流七 ンサ用希土類鉄ガーネット材料とセンサ 光学系の研究開発に従事。

電学論C, 112 巻 12 号, 平成 4 年 